\title{
HUMAN RESOURCE MANAGEMENT IN SPORTS JUDGING FROM THE SPORTS DEVELOPMENT INDEX ON INCREASING SPORTS ACHIEVEMENT IN SAMARINDA CITY
}

\author{
Muhammad Ramli Buhari ${ }^{1 *}$, Nurjamal ${ }^{2}$, Muchamad Samsul Huda ${ }^{3}$, Didik

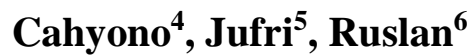 \\ ${ }^{123456}$ Physical Education, Faculty of Teacher Training and Education, Universitas Mulawarman, \\ Samarinda, Indonesia
}

\section{Article Info}

Article History :

November 2021

Received : December 2021

Revised : December

2021

Accepted : December 2021

Available online :

December 2021

Keywords:

Management, human resources, sports development index

\begin{abstract}
This study aims to determine the management of sports human resources in the city of Samarinda in terms of the Sports Development Index (SDI). The research was conducted in 10 subdistricts in Samarinda City, taking data from 3 institutions as the scope of research, namely the Department of Education, KONI/DISPORA Samarinda, and other Non-Formal Institutions. Research methods use a survey method with a quantitative descriptive approach in terms of SDI. The research instruments used are observation, interview, and analysis of documents. The results of this study indicate; The sports HR Index at the Education Department 0.5009 falls into the middle category, the KONI/DISPORA sports HR Index of 0.2907 in the low category, and the Non-Formal Institution's sports HR Index 0.0736 is a low category. Overall, the Sports HR Index in 10 sub-districts in Samarinda City of 0.00086 is low.
\end{abstract}

Corresponding address : Jl. Kuaro, Gn. Kelua, Kec.

Samarinda Ulu, Kota Samarinda, Kalimantan Timur

*Corresponding email : m.ramli@fkip.unmul.co.id
ISSN 2685-6514 (Online)

ISSN 2477-331X (Print) 


\section{INTRODUCTION}

As one of the main elements in an organization, Human Resources (HR) requires a sound management system so that organizational performance can run optimally. HR is all the potential humans have in the form of mind, energy, skills, emotions, and other possibilities that can meet needs and desires or achieve organizational goals efficiently and efficiently. HR management is a process that involves aspects of planning, organizing, directing, and supervising. (Irfandi, M.Or Zikrur Rahmat, 2017).

In-Law No. 3 of 2005 on the National Sports System mentioned that the pillar of sports concerns sports achievement and educational sports and recreational sports. These three pillars are the key to sports development that can be carried out in stages in Indonesia (Kusumiadi et al., 2021). The availability of Human Resources of Sports (HRS) guarantees that all sports activities are supported by sports personnel who have competencies that can be accounted for academically and professionally. According to (Pujiutomo et al., 2021), human resources are needed to move the sport both informal institutions such as schools and nonformal relaxed such as clubs and in open spaces commonly used by sports players. This means that the quality and competence of HR who handles sports must be empowered to support sports coaching and development at both the regional, national, and international levels.

Based on the needs of users, the type of HRS that must be developed and improved in the quality and competence in this study is related to the number of Physical Education (PE) teachers, coaches, sports instructors, and referees owned by a province/district/city/sub-district. The existence of component HRS in adequate quantities can impact sports activities in the community both regarding quality and quantity (Adiyudha Permana, 2016). To achieve this goal, the government of Samarinda city must manage, carry out, and foster by their authority and responsibilities. The coaching system should provide guarantees for everyone's ease to participate and achieve maximum participation, in addition to providing opportunities for talent development in the field of sports (Andri Arif Kustiawan, 2020). The function of management science is the answer to the management and development of the HRS.

Sports Development Index (SDI) is a new alternative that can determine how well the level of sports development in one region (Pradhana, 2016). According to (Basic \& Decheline, 2017) SDI refers to a combined index that can reflect the success of sports development based on four primary dimensions, namely; (a) availability of open space, (b) human resources, (c) community participation in sports, (d) community fitness. But in this study only focused on HRS. HRS values are measured based on the ratio between the number of HRS itself such as; coaches, referees, sports instructors and physical education teachers with a population of seven years and above in the area or region. (Bafirman, 2020).

In Samarinda city, determining the level of progress in sports development has 
never been studied scientifically through indepth research. During this time, the progress of sports tends to be based on the acquisition of medals in multievent sports activities such as PON or PORPROV. Availability of HRS; PE teacher's, coaches, referees, and instructors, both of quantity and quality, have no accurate data. Likewise, in terms of management starting from the process of planning, organizing, actuating and control. In the future, the use of artificial intelligence, extensive data analysis, and other technologies in sports training data management and analysis has more room for development (Li et al., 2021).

Thus, the results of this study will be able to present a measure of progress in sports development that is more adequate and more thorough than the size of medals alone. The general information revealed through SDI will help make sports development policies in Samarinda city, especially related to efforts to improve sports achievements and create a fundamental and robust sports development structure supported by competent HR management in sports.

\section{METHODS}

This research uses descriptive methods qualitative and quantitative. Qualitative data is collected through observation, document analysis and interviews to find out the management of sports HR to improve sports achievement in Samarinda city. In contrast, quantitative data is taken using SDI norm methods to analyze the availability of human resources to sports.
The index presents data in the form of numbers then described (Pujiutomo et al., 2021). The index will provide an operational explanation of the service requirements of minimal sports in Samarinda city.

\section{Participants}

Participants in this study were HRS spread across ten sub-districts in Samarinda city. The HRS in question is a teacher/ lecturer of physical education, sports instructor, coach, and referee. Male and female. Have a certificate or who doesn't have a certificate.

\section{Sampling Procedures}

Using purposive sampling techniques, research informants obtain data sources to produce samples that logically represent the population. This study is emphasized to be a sample due to consideration of specific characteristics or characteristics, namely several teachers/lecturers of physical education, sports instructors, coaches, and referees spread across ten sub-districts in Samarinda city. The procedure is through observation and analysis of documents from the Department of Education, Universities, KONI/DISPORA, Sports Administrators and Non-Formal Institutions that handle recreational sports.

\section{Materials and Apparatus}

The materials and equipment used in this study are (a) Form guidelines interview about interview data collection techniques, 
(b) Form guidelines data collection techniques, and (c) Media other supporting such as tape recorder, camera, and notebook.

\section{Procedures}

After several HRS obtained from 10 subdistricts in Samarinda city, calculate the availability index of sports HR in each of these sub-districts. The procedure: first, looking for the actual value is the value obtained from the division results between the amount of HRS with the number of residents over seven years. The maximum value of HRS specified in SDI is 2.08, and the minimum value is 0.00 . After all the number are obtained, it is then calculated using the formula.

HRS Indeks $=\frac{(\text { Actual Value }- \text { Minimum Value })}{(\text { Maximum Value }- \text { Minimum Value })}$

Furthermore, after getting the index value, the last stage determines the category or norm of the index value obtained. The SDI norms used are:

Table 1. Norms of Sports Development Index

\begin{tabular}{cll}
\hline No & $\begin{array}{l}\text { Index } \\
\text { Numbers }\end{array}$ & Categories \\
\hline 1 & $0.800-1.000$ & Tall \\
\hline 2 & $0.500-0.799$ & Intermediate \\
\hline 3 & $0.000-0.499$ & Low \\
\hline Source: (Purwono et al., 2019)
\end{tabular}

\section{Design or Data Analysis}

The research process is a systematic and logical step that is carried out in conducting research methods. The research steps are based on the following research flow diagram:

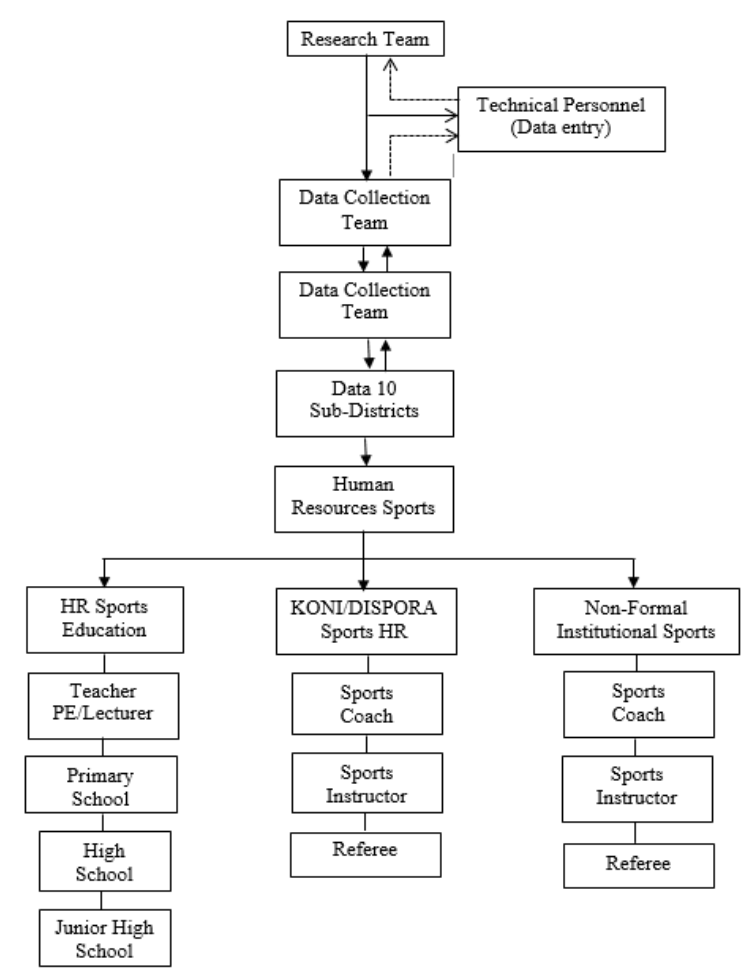

Figure 1. Research Flow Diagram

Data analysis techniques in quantitative research can be obtained from various sources, using data collection techniques, namely primary data and secondary data. Preliminary data consists of HRS data, while secondary data is data on populations over seven years.

To collect primary data in this study, there are three types of data collection techniques: (a) Direct observation, (b) Structured interviews, (c) Documentation studies in the form of archives used as supporting data.

The data view is done using a short description and table. The brief description is based on the results of observations, interviews, and documentation. In contrast, the table is based on the norms/categories of 
SDI for the HRS index in the city of Samarinda.

\section{RESULT}

Data observation of the availability of HRS in 10 sub-districts in Samarinda city is known as follows:

Table 1. The results of word of sports HR per Subdistrict in Samarinda City

\begin{tabular}{|c|c|c|c|c|c|c|c|c|}
\hline No & District & $\begin{array}{l}\text { Population } \\
\text { (27 years) }\end{array}$ & $\begin{array}{l}\text { Number } \\
\text { of } \mathrm{HR}\end{array}$ & $\begin{array}{l}\text { Actual } \\
\text { Value }\end{array}$ & $\begin{array}{l}\text { Max } \\
\text { Value }\end{array}$ & $\begin{array}{l}\text { Min } \\
\text { Value }\end{array}$ & $\begin{array}{c}\text { HR } \\
\text { value }\end{array}$ & Category \\
\hline 1 & Palaran & 56.782 & 137 & 0.0024 & 2.08 & 0.00 & 0.0012 & Low \\
\hline 2 & Samarinda Ilir & 62.735 & 98 & 0,0016 & 2.08 & 0.00 & 0.0008 & Low \\
\hline 3 & $\begin{array}{l}\text { Samarinda } \\
\text { Seberang }\end{array}$ & 57.642 & 108 & 0,0019 & 2.08 & 0.00 & 0.0009 & Low \\
\hline 4 & $\begin{array}{l}\text { Sungai } \\
\text { Kuniang }\end{array}$ & 127.136 & 174 & 0,0014 & 2.08 & 0.00 & 0.0007 & Low \\
\hline 5 & Samarinda Ulu & 123.399 & 184 & 0,0015 & 2.08 & 0.00 & 0.0007 & Low \\
\hline 6 & $\begin{array}{l}\text { Samarinda } \\
\text { Utara }\end{array}$ & 100.335 & 198 & 0,0020 & 2.08 & 0.00 & 0.0010 & Low \\
\hline 7 & Sambutan & 51.534 & 102 & 0,0020 & 2.08 & 0.00 & 0.0010 & Low \\
\hline 8 & Sungai Pinang & 99.563 & 131 & 0,0013 & 2.08 & 0.00 & 0.0006 & Low \\
\hline 9 & $\begin{array}{l}\text { Samarinda } \\
\text { Kota }\end{array}$ & 25.311 & 133 & 0,0053 & 2.08 & 0.00 & 0.0026 & Low \\
\hline 10 & Loa Janan Ilif & 59.485 & 110 & 0,0018 & 2.08 & 0.00 & 0.0009 & Low \\
\hline
\end{tabular}

Data from HRS observations in 10 sub-districts in Samarinda city showed a low category.

Data the results of observation of the availability of HRS spread across ten subdistricts in Samarinda city include; HR Samarinda City Education Office, HRS KONI/DISPORA Samarinda city, and HRS Institution Non-formal Samarinda city can be seen from the following table:

Table2. The results of HRS observations of Samarinda City Education Department

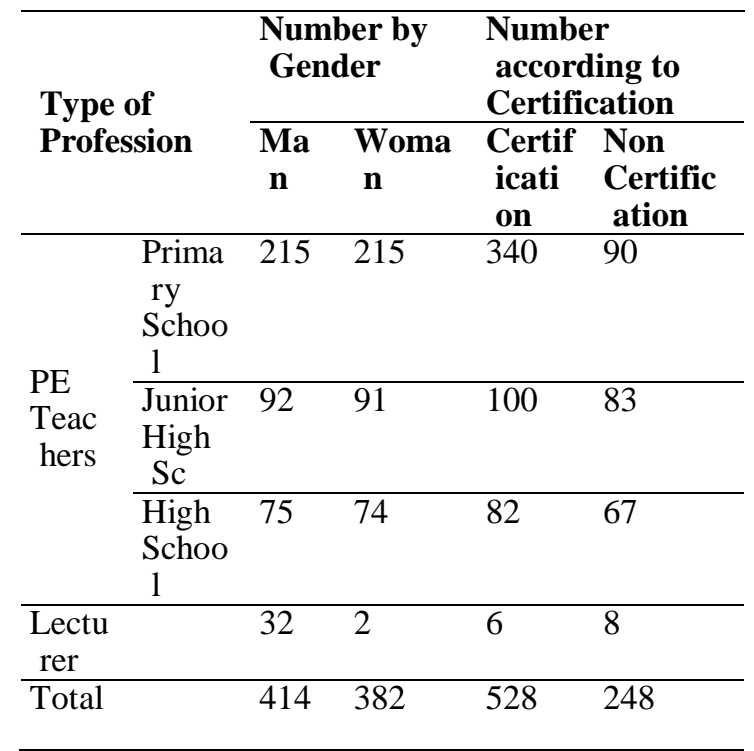

Table 2 shows that the number and quality of HRS in the Samarinda city Education Department are 796 people. The population over the age of 7 years in Samarinda city is about 763,922 residents. Then obtained the actual value: 796/763. $922=1.0420$. This means the HRS index of the Samarinda city Education Office shows the middle category of 0.50096 . Obtained from the following formula

$$
\begin{aligned}
\text { HRS Indeks } & =\frac{(\text { Actual Value }- \text { Minimum Value })}{(\text { Maximum Value-Minimum Value })} \\
\text { HRS Indeks } & =\frac{(1,0420-0,00)}{(2,08-0,00)} \\
\text { HRS Indeks } & =0,50096
\end{aligned}
$$

\begin{tabular}{|c|c|c|c|c|}
\hline \multirow{2}{*}{$\begin{array}{l}\text { Type of } \\
\text { Professi } \\
\text { on }\end{array}$} & \multicolumn{2}{|c|}{$\begin{array}{c}\text { Number by } \\
\text { Gender }\end{array}$} & \multicolumn{2}{|c|}{$\begin{array}{c}\text { Number according to } \\
\text { Certification }\end{array}$} \\
\hline & $\begin{array}{l}\text { Ma } \\
\text { n }\end{array}$ & $\begin{array}{l}\text { Wom } \\
\text { an }\end{array}$ & $\begin{array}{l}\text { Certifica } \\
\text { tion }\end{array}$ & $\begin{array}{l}\text { Non } \\
\text { Certifica } \\
\text { tion }\end{array}$ \\
\hline $\begin{array}{l}\text { Sports } \\
\text { Coach }\end{array}$ & 116 & 82 & 153 & 45 \\
\hline $\begin{array}{l}\text { Sports } \\
\text { Instruct } \\
\text { or }\end{array}$ & 24 & 31 & 37 & 18 \\
\hline Referee & 145 & 65 & 210 & 0 \\
\hline
\end{tabular}

Table3. Observation Results Of $\mathrm{Hr}$ Koni/Dispora Samarinda City 


\begin{tabular}{lllll}
\hline Total & 284 & 178 & 400 & 63 \\
\hline
\end{tabular}

Table 3 shows that the number and quality of HR KONI/DISPORA Samarinda city have as many as 462 people. The population over the age of 7 years in Samarinda city is about 763,922 residents. Then obtained the actual value: $462 / 763$. $922=0.6048$. This means that the KONI/DISPORA sorts HR index in Samarinda city shows a low category of 0.29076. Obtained from the following formula:

HRS Indeks $=\frac{(\text { Actual Value }- \text { Minimum Value })}{(\text { Maximum Value-Minimum Value })}$

HRS Indeks $=\frac{(0,6048-0,00)}{(2,08-0,00)}$

HRS Indeks $=0,29076$

Table 4. The results of observation of HRS Institusi Non-Formal in Samarinda City

\begin{tabular}{lllll}
\hline $\begin{array}{l}\text { Type of } \\
\text { Professi } \\
\text { on }\end{array}$ & \multicolumn{2}{c}{$\begin{array}{l}\text { Number by } \\
\text { Gender }\end{array}$} & $\begin{array}{l}\text { Number according to } \\
\text { Certification }\end{array}$ \\
\cline { 2 - 5 } & $\begin{array}{l}\text { Ma } \\
\text { nom }\end{array}$ & $\begin{array}{l}\text { an } \\
\text { an }\end{array}$ & $\begin{array}{l}\text { Certifica } \\
\text { tion }\end{array}$ & $\begin{array}{l}\text { Non } \\
\text { Certifica } \\
\text { tion }\end{array}$ \\
\hline $\begin{array}{l}\text { Sports } \\
\text { Coach }\end{array}$ & 27 & 23 & 32 & 18 \\
\hline $\begin{array}{l}\text { Sports } \\
\text { Instruct } \\
\text { or }\end{array}$ & 32 & 14 & 5 & 41 \\
\hline Referee & 13 & 8 & 6 & 15 \\
\hline Total & 72 & 45 & 43 & 74 \\
\hline
\end{tabular}

Table 4 shows that the number and quality of HRS Instutusi Non-Formal of Samarinda city have as many as 117 people. The population over the age of 7 years in Samarinda city is about 763,922 residents. Then the actual value is obtained: $117 / 763$. $922=0.1532$. This means that the HRS NonFormal Istutusi index in Samarinda city shows a low category of 0.07365 . Obtained from the following formula:

HRS Indeks $=\frac{(\text { Actual Value }- \text { Minimum Value })}{(\text { Maximum Value }- \text { Minimum Value })}$

HRS Indeks $=\frac{(0,1532-0,00)}{(2,08-0,00)}$

HRS Indeks $=0,07365$

Table 2, 3, and 4 mentioned above shows that the number and quality of HRS in Samarinda city has as many as 1,375 people. The population over the age of 7 years in Samarinda city is about 763,922 residents. Then obtained the actual value: $1.375 / 763$. $922=0.0018$. This means that the existing HRS index in Samarinda city shows a low category of 0.0086. Obtained from the following formula:

HRS Indeks $=\frac{\text { (Actual Value }- \text { Minimum Value })}{\text { (Maximum Value }- \text { Minimum Value })}$ HRS Indeks $=\frac{(0,0018-0,00)}{(2,08-0,00)}$

HRS Indeks $=0.0086$

Thus, the overall index of HRS results in Samarinda city is as follows:

Table 4. Observations results HRS in Samarinda City

\begin{tabular}{llll}
\hline No & Agency & $\begin{array}{l}\text { HR } \\
\text { Value }\end{array}$ & Category \\
\hline 1 & Education & 0.5009 & $\begin{array}{l}\text { Intermediat } \\
\text { Department }\end{array}$ \\
& & \\
& HR & & \\
& Index & & \\
\hline 2 & KONI/DISPO & 0.2907 & Low \\
& RA & & \\
& HR Index & & \\
\hline 3 & Non-formal & 0.0736 & Low \\
& Institutional & & \\
& HR & & \\
& Index & & \\
\hline 4 & Samarinda City & 0.00086 & Low \\
& Sports HR & & \\
& Index & & \\
\hline
\end{tabular}


Reviewed from the management aspect based on document analysis and interviews found as follows: (a) Planning: Planning management has been going well. This is evidenced by the determination of organizational goals, policy, coaching and refereeing programs, development programs and procurement of facilities and infrastructure, working methods, work systems, and standards of each part of the organization needed to achieve organizational goals. But it was also found that some organizations did not have systematic planning and tiered programs to improve sports achievement and did not have adequate planning for sports achievement coaching. (b) Organizing: Organizational development management has been going well. This is evidenced by the arrangement of organizational management structures in each sports board. Every field in the organization has a straightforward program and division of staff work, and each manager knows the mechanism of work of each lot. Although some staff do not have a sports background, this organization still empowers existing people to the fullest. (c) Actuating: The organization's actuating management has been going well. All sports organization administrators always maintain unified communication and relationships so that orders, reports, information, news, and advice can be appropriately received to cooperate between administrators in carrying out activities. As the driver of activities, the leader constantly monitors and motivates subordinates who will work so that everyone works optimally with the responsibilities carried out. (d) Control: The control process is already going well. Sports organizations always involve administrators in essential discussions and information about the progress of work programs in sports achievement coaching efforts. The leader always oversees the implementation and activities of its members in the performance of the training program. Included in the recruitment of coaches and athletes.

\section{DISCUSSION}

Sports Development Index is a new alternative that can determine the level of sports development in one region (Pradhana, 2016). The concept of SDI has a broader scope than other concepts, such as medals used as a single indicator of sports success. SDI is the answer to government policies related to sports development in a region, whether it has succeeded or failed.

According to (Adiyudha Permana, 2016; Andri Arif Kustiawan, 2020) the quality and competence of human resources who handle sports must be empowered to support sports coaching and development at the regional, national, both for sports achievement, sports education and recreational sports.

If you look at the ratio of SDI calculations that have been done in 10 subdistricts in Samarinda city is still in the category of low in the range of 0.00086 . It can be said that there is a lot of HRS related to teachers, coaches, referees, and in structure. It becomes a choir for the local government to improve it. The government should make policies regarding the 
development and improvement of the quality and quantity of HRS. Focus on strengthening HR coaches for sports achievement, instructors for recreational sports, and Physical Education (PE) teachers. (Setiawan et al., 2019) stated that the essential nature of sports human resources is to ensure that all sports activities are supported by sportsmen who have competencies that can be accounted for ethically, professionally, and academically.

Teachers, referees, and instructors are significant components of the sports coaching system. The availability of teachers in PE in each school inadequate numbers will encourage sports education activities in schools. This condition will stimulate interest and sporting talent in students. PE teachers are responsible for body processing activities designed to improve physical fitness, develop motor skills, knowledge, healthy and active living behaviours, sportsmanship, and intelligence to improve the quality of human resources. According to (Andri Arif Kustiawan, 2020) the existence of PE teachers in each school inadequate numbers will encourage sports activities in schools to be more exciting and varied; the condition will, in turn, stimulate the interest and talent of students exercising.

A coach is an expert in his field who is responsible for assisting and training athletes and teams in improving the appearance and performance of athletes. Sports human resources referred to in sports achievement should be a coach who is educated and understands well the problems that concern coaching; this will have a much greater possibility than not having the basis of coaching science. A coach should know about all the needs that are the basis for fulfilling the conditions in which athletes can achieve achievements (Bangun, 2019).

The job of sports instructors is responsible for leading and moving sports activities that are popular in the community. Sports instructors who teach sports activities are physical fitness gymnastics, aerobic gymnastics, and fitness instructors in fitness centres.

Sports referee is HR who oversees being aware and making decisions in a match/sports match. A referee must have the qualifications, license, certification of the referee of the appropriate parent sport and preside over the fight fairly and impartially.

The development of the sport will largely depend on the quantity and quality of its human resources. Therefore, the Samarinda city government must immediately improve and start preparing HRS that have competencies that can be accounted for academically and professionally by the demands of the law. The achievement of the sports development index figure of 0.800-1,000 absolutely must be fought gradually and spread across every sub-district in the city of Samarinda.

The quality and competence of HR who handle sports must be empowered to support sports coaching and development both at the regional, national, both for sports achievement and community sports (Adiyudha Permana, 2016). This is supported by an optimal certification from experts so that the quality of HR is not in doubt. Therefore, HR is intended to be a coach of achievement sports, recreational 
sports instructors, and PE teachers for educational sports. With a conducive system utilising the three HR, an area is believed to achieve achievements, and sports development will progress.

Surveys conducted by several sports coaches still exist who do not provide coaching or have never followed the management of coaches and the like. Whereas HRS significantly affects the achievement and development of sport in Samarinda city. HRS is many and quality, of course as the basis for sports development in Samarinda city.

Take the example of the North Samarinda sub-district, which is the centre of sports activities because it is equipped with many sports facilities and infrastructure, but HRS are still very few. It becomes lame. It will be different if the human resources are many and supported by good facilities and infrastructure. One of them is forming sports communities in each sub-district, such as the Massage Sports Community, the Sports Doctors Community, the Sports Management Community, and the Sport Coach Community. These communities are expected to contribute and can help the development of sports in Samarinda City optimally.

Similarly, in Sambutan District, it is necessary to improve preparation HR and sports facilities and infrastructure that support improving sports achievements. The results of observations on the field did not find referees/judges branch of boxing sports, still the lack of chess coaches and some martial arts sports. There are two referees of sepak takraw; there is no athletic coach, even though there is already a sports organisation.

About management, it can be interpreted as responsibility for the appearance or performance of the sport. Good sports management will boost a person's success rate in a sport because sports overshadows many essential parts that must be controlled to be used as a tool to achieve a goal.

According to (Irfandi, M.Or Zikrur Rahmat, 2017), management can be interpreted as a process that involves aspects of planning, organising, actuating and control. This can be the point that sports management is a combination of skills of the cow related to planning, organising, leadership, governance, budgeting, and evaluation in nature of a context organisation yang has the main product related to sports.

Every sport will require management because jokes consist of groups of people who work together to achieve goals. For good cooperation in a sport, it is necessary to organise and manage properly and run systematically through stages that begin with a planning process. According to (Yudha Febrianta, 2014), developing an integrative sports management system will ensure the realisation of sports culture in the framework of practising sports and cultivating society, or culture of achievement to improve dignity and worth.

Management in sports coordinates all available resources, including HR, materials, technology, and finance, that humans require to achieve their goals. Management provides direction and 
guidance that can bring together a wide variety of individuals in the production business. According to (Kautsar et al., 2019) the orientation of management lies in its processes, which means that management requires $\mathrm{HR}$, knowledge and skills for activities to be more effective or able to produce action in achieving goals.

The goal of sports management is the success of sports players in improving sports achievement. Leadership is needed because we are constantly faced with challenges in the scarcity of resources (Irfandi, M.Or Zikrur Rahmat, 2017).

\section{CONCLUSION}

Overall, the HR index of sports in 10 sub-districts in Samarinda city is as follows: (a) The HR index in Samarinda city of 0.00086 falls into the low category. (b) The sports HR Index at the Education Department in Samarinda city of 0.5009 belongs to the middle category. (c) The sports HR index in KONI / DISPORA Samarinda City of 0.2907 falls into the low category. (d) The sports HR Index at NonFormal Institutions in Samarinda City of 0.0 736 falls into the low category.

\section{ACKNOWLEDGEMENT}

This work is financially supported by unlimited research grants provided by the Faculty of Teacher Training and Education, Mulawarman University.

\section{REFERENCES}

Adiyudha Permana, P. S. B. (2016). Tingkat Partisipasi Olahraga dan Ketersediaan SDM Keolahragaan Kota Pontianak Provinsi Kalimantan Barat Ditinjau dari Sport Development Index (SDI). Jurnal Pendidikan Olahraga, 4(1), 9-19.

Andri Arif Kustiawan. (2020). Sport Development Index (SDI) Di Kabupaten Pacitan. Journal of Chemical Information and Modeling, 53(9), 1689-1699.

Bafirman, H. B. (2020). Peningkatan Kompetensi Ikatan Sarjana Olahraga Indonesia Melalui Pengkajian Sport Development Indeks. 5(1), 81-94.

Bangun, S. Y. (2019). Peran Pelatih Olahraga Ekstrakurikuler Dalam Mengembangkan Bakat Dan Minat Olahraga Pada Peserta Didik. Jurnal Prestasi, 2(4), 29. https://doi.org/10.24114/jp.v2i4.11913

Dasar, S., \& Decheline, G. (2017). Hasil Pembangunan Olahraga Di Kota Jambi Ditinjau. Pendidikan Jasmani Dan Olahraga, 2(2), 61-71.

Irfandi, M.Or Zikrur Rahmat, M. P. (2017). Irfandi, M.Or Zikrur Rahmat, M.Pd. Yuma Pustaka. https://repository.bbg.ac.id/bitstream/453 /1/Manajemen_Penjas_dan_Olahraga.pdf Kautsar, A., Sumardiyanto, S., \& Ruhayati, Y. (2019). ANALISIS FUNGSI MANAJEMEN ORGANISASI OLAHRAGA (Studi Kualitiatif Pada Pengurus Daerah Ikatan Sport Sepeda Indonesia Jawa Barat). Jurnal Terapan Ilmu Keolahragaan, 3(2), 41-45. https://doi.org/10.17509/jtikor.v3i2.1013 5

Kusumiadi, Nuryadi, \& ma'mun. (2021). Program Pembangunan Olahraga pada Pemerintahan Kabupaten Bandung Barat 
Tahun 2019. Jurnal Ilmu Keolahragaan, 19(2), 73-78.

Li, H., Zhang, H., \& Zhao, Y. (2021). Design of computer-aided teaching network management system for college physical education. Computer-Aided Design and Applications, 18(s4), 152-162. https://doi.org/10.14733/CADAPS.2021. S4.152-162

Pradhana, A. (2016). Analisis Sport Development Index Kecamatan Ngronggot Kabupaten Nganjuk. Jurnal Kesehatan Olahraga, 4(4), 2-7.

Pujiutomo, H., Harjono, H. S., Magister, P., Pendidikan, T., \& Index, S. D. (2021). Jurnal cerdas sifa pendidikan. 10, 24-33.

Purwono, E. P., Irsyada, R., Setiawan, I., \& Abdulaziz, M. F. (2019). Improvement Quality of Physical Education Reviewed by Sports Development in Pekalongan. 362(Acpes), 192-195. https://doi.org/10.2991/acpes-19.2019.43

Setiawan, I., Abdulaziz, M. F., Purwono, E. P., \& Irsyada, R. (2019). Sports Development Reviewed by SDI to Improve The Quality of Physical Education With Conservation Character. 362(Acpes), 292-296. https://doi.org/10.2991/acpes-19.2019.66 Yudha Febrianta. (2014). Manajemen-OlahragaAbad-21.Pdf. In Prosiding Seminar Nasional "Optimalisasi Peran Pendidikan dalam Membangun Karakter Anak untuk Menyongsong Generasi Emas Indonesia (pp. 217-221). 